\title{
EFFECTS OF LOW TEMPERATURES ON ENZYME ACTIVITY, CHLOROPHYLL AND ION CONTENTS IN COMMON BEAN GENOTYPES
}

\author{
KABAY, T. \\ Ercis Vocational School, Van Yuzuncu Yil University, Van, Turkey \\ (e-mail: tkabay@yyu.edu.tr; phone: +90-532-205-1624; fax: +90-432-225-1104) \\ (Received $14^{\text {th }}$ Aug 2018; accepted $15^{\text {th }}$ Oct 2018)
}

\begin{abstract}
Low temperatures slow down plant growth and development and generate physiological damages on plants. Metabolism of largely produced and consumed common bean (Phaseolus vulgaris L.) plants decelerates at temperatures below $15{ }^{\circ} \mathrm{C}$. This study was carried out at Van Yuzuncu Yil University in Van province of Turkey with limited vegetation period due to its cold climate in winter. In this study, the bean plants were subjected to low temperature stress and catalase (CAT), super oxide dismutase (SOD), ascorbate peroxidase (APX) enzyme activities, malondialdehyde (MDA), chlorophylla, chlorophyll-b and total chlorophyll, $\mathrm{K}, \mathrm{Ca}$, and $\mathrm{Mg}$ ion contents of low temperature stress-tolerant Yakutiye and Ç30 and low temperature stress-sensitive Zulbiye and Ç13 bean genotypes were measured on $25^{\text {th }}, 30^{\text {th }}, 35^{\text {th }}$ and $40^{\text {th }}$ days of low temperature stress. Four bean seeds were sown in 2-liter pots filled with 2:1 peat:perlite mixture as to have 2 plants in each pot. The pots were irrigated with Hoagland nutrient solution. Low temperature stress plants were sown on $15^{\text {th }}$ of March with low outdoor temperatures. In control group, been seeds were sown on $25^{\text {th }}$ of April and plant samples were taken in again 5-day intervals in 4 periods $\left(25^{\text {th }}, 30^{\text {th }}, 35^{\text {th }}\right.$ and $40^{\text {th }}$ days of growth). Significant differences were observed in enzyme activities, chlorophyll contents and ion contents of low temperature-tolerant and sensitive bean genotypes in 4 measurement periods.
\end{abstract}

Keywords: abiotic stress, biochemical characteristics, nutrient, Phaseolus vulgaris, physiological characteristics

\section{Introduction}

In terrestrial climate zones, low bean yields are generally attributed to prominent climate conditions of the regions. Seed germination in beans largely depends on genotypes and quite a few genotypes are able to well-germinate at temperatures below $10{ }^{\circ} \mathrm{C}$. In vegetables, low temperatures at root zone generate a stress in water absorption of the roots (Sakamoto and Suzuki, 2015). Beans are generally sensitive to cold temperatures, thus germination rates and percentages decrease at low soil temperatures in spring. Water absorption damage increases because of rapid water intake and ultimately seedling formation greatly weakened. In cold climates, temperatures often go below $15{ }^{\circ} \mathrm{C}$ during the initial growth stages of the seedlings and such low temperatures then negatively influence seedling growth and development (Elkoca et al., 2005). Plants develop different mechanism against cold stress-induced damages and ultimate die outs or to provide cold-tolerance. Exothermic effects of inner and intra cell frost formation on plants are categorized as physical changes in cell membranes throughout cold-stress period, cold resistance and acclimatization and biochemical changes throughout the cold acclimatization (changes in some soluble substances in plant extract, lipid composition of cell membranes, protein contents, enzyme activity and antioxidant systems (Aslantaş et al., 2010).

Abiotic stress factors negatively affect several crops. Significant decreases were reported in photosynthesis rates and chlorophyll contents of pea plants when the plants were subjected to $45^{\circ} \mathrm{C}$ temperature for $24 \mathrm{~h}$ (Georgieva et al., 2007). Decreasing 
chlorophyll, $\mathrm{K}$ and $\mathrm{Ca}$ contents and increasing MDA, CAT, SOD and APX activities were reported for bean and tomato plants under drought and high temperatures (Terzi et al., 2010; Kabay and Şensoy, 2016, 2017; Alp and Kabay, 2017).

It was reported in a previous study investigating the effects of low temperature stress on physiological characteristics of tomato genotypes that cold stress reduced chlorophyll and dry matter content of young and old leaves and wakened antioxidative systems of the plants (Gökmen, 2006). Low temperatures were reported to increase antioxidant enzyme and MDA content of rapeseed plants (Xian et al., 2017). Low temperatures increase chlorophyll and weight losses of cabbages and increased reactive oxygen species (Soengas et al., 2018).

It was indicated in another study carried out with cold stress-resistant and sensitive sugar cane cultivars that sensitive cultivar had greater root length and root volume than the resistant cultivar, but cell structure was destructed in both cultivars and cold stressinduced plants had greater MDA, proline, soluble sugar, soluble protein, POD and SOD activity than the control plants (Sun et al., 2017).

It was reported in another study investigating the effects of cold stress on rye and wheat seedlings that cold stress increased antioxidant enzyme activities, proline, sugar and anthocyanins contents of both species (Kolupaev et al., 2016).

Significant decreases were reported in malondialdehyde, proline, peroxidase and catalase activities of control and transgenic tomato plants under cold and low temperature stress ( $\mathrm{Yu}$ et al., 2015). Xintaimici and Jinyan cucumber (Cucumis sativus L.) cultivars were subjected to two different temperature regimes $\left(15 / 15^{\circ} \mathrm{C}\right.$ and $25 / 18^{\circ} \mathrm{C}$ ) under low light intensity and significant increases were reported in leaf superoxide dismutase and guaiacol peroxidase activities of both cultivars and less increases were reported in leaf catalase activity (Xu et al., 2008). Ogweno et al. (2009) reported different photosynthetic physiological responds of tomato leaves to moderate and low temperature stress. Huang et al. (2018) reported decreasing net photosynthetic rate and chlorophyll contents of Akihime and Benihoppe strawberry cultivars under cooling stress. Researchers also reported that foliar selenium (Se) sprays relieved the decrease in net photosynthetic rate and chlorophyll content and increased malondialdehyde and hydrogen peroxide content under stress conditions. Do et al. (2018) reported increasing ascorbate peroxidase (APX) and superoxide dismutase (SOD) activities of melon and pumpkin plants when they were subjected to $12 / 7^{\circ} \mathrm{C}$ (day/night) low temperatures for $0-72 \mathrm{~h}$. Li et al. (2018) reported that cold stress increased the accumulation of reactive oxygen species (ROS) and resulted in an oxidative stress, such a case then decreased photosynthetic processes of tea leaves, but melatonin treatments reduced antioxidant potential and oxidative stress and increased photosynthetic capacity. Bilska-kos et al. (2017) reported that low temperatures $\left(14 / 12{ }^{\circ} \mathrm{C}\right)$ altered pectin content and osmatic potential of maize leaf cells and ultimately altered cell membrane composition. Zhou et al. (2017) reported significant decreases in fresh and dry weights, leaf areas and relative water contents of tomato cultivars under drought stress as compared to the control plants. While significant increases were reported in antioxidant compound quantities of tomato plants, decreases were reported in chlorophyll contents (Gökmen, 2006). It was reported in study carried out to determine yield and total temperature demands of bean plants at different growth stages that the greatest yield was obtained from early July sowings and yields decreased as the sowing time approached to autumn (Yoldaş and Eşiyok, 2009). High and low temperatures $\left(15 / 8,20 / 13,28 / 21,33 / 23\right.$ and $\left.36 / 26^{\circ} \mathrm{C}\right)$ were applied to tomato plants 
and it was observed that temperature stress negatively influenced plant growth and development and nutrient uptake (Sung et al., 2015).

This study was carried out to determine the effects of low temperature stress on enzyme activity, chlorophyll, $\mathrm{K}, \mathrm{Ca}$ and $\mathrm{Mg}$ contents of low temperature tolerant (Yakutiye and Ç30) and sensitive (Zulbiye and Ç13) common bean (Phaseolus vulgaris L.) genotypes.

\section{Materials and methods}

This study was conducted to determine the effects of low temperature stress on common bean genotypes. The study carried out at the Greenhouses of Van Yuzuncu Yil University Erciş Vocational Collage of Turkey and the plant analyses were carried out at laboratories of the Agricultural Faculty of the same university. Catalase (CAT), super oxide dismutase (SOD), ascorbate peroxidase (APX) enzyme activities, malondialdehyde (MDA), chlorophyll-a, chlorophyll-b and total chlorophyll, $\mathrm{K}, \mathrm{Ca}$, and $\mathrm{Mg}$ ion contents of low temperature stress-resistant Yakutiye and Ç30 and low temperature stress-sensitive Zulbiye and Ç13 bean genotypes (Fig. 1) were measured on $25^{\text {th }}, 30^{\text {th }}, 35^{\text {th }}$ and $40^{\text {th }}$ days of low temperature stress. For low temperature stress, bean seeds were sown in 2-liter pots filled with 2:1 peat:perlite mixture on $15^{\text {th }}$ of March with low outdoor temperatures in a plastic covered high tunnels. Four seeds were placed in each pot as to have 2 plants in each pot. Pots were irrigated with Hoagland nutrient solution. The initial samples were taken from 25-days old plants and high tunnel cover was removed. Plants were then exposed to outdoor conditions and plant samples were taken in 5-day intervals $\left(25^{\text {th }}, 30^{\text {th }}, 35^{\text {th }}\right.$ and $40^{\text {th }}$ days $)$ in 4 periods. High-tunnel temperature was $16.76^{\circ} \mathrm{C}$ in day time and $15.28{ }^{\circ} \mathrm{C}$ at night. When the tunnel cover was removed, day temperature was measured as $12.67^{\circ} \mathrm{C}$ and night temperature was measured as $8.43{ }^{\circ} \mathrm{C}$ by Hobo temperature data loggers. In control group, bean seeds were sown on $25^{\text {th }}$ of April into the pots placed in a high-tunnel and plant samples were taken in again 5 -day intervals on $25^{\text {th }}, 30^{\text {th }}, 35^{\text {th }}$ and $40^{\text {th }}$ days of growth. Throughout the experiments, day temperature was measured as $27.44^{\circ} \mathrm{C}$ and night temperature was measured as $16.87^{\circ} \mathrm{C}$. The analyses performed on plant samples are provided below.

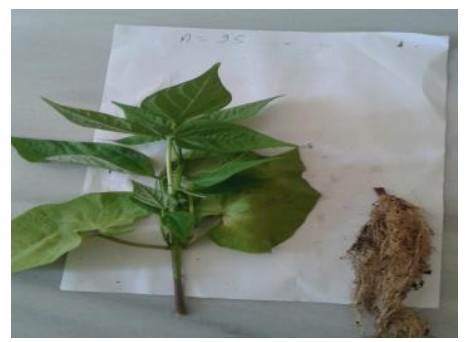

Control

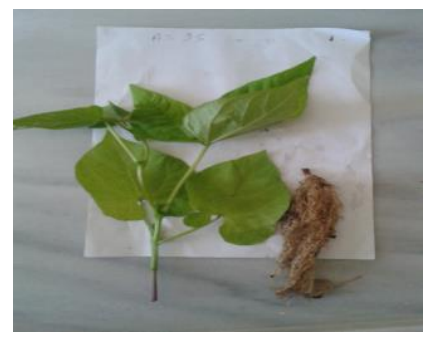

Low temperature

Figure 1. A view of control and low temperature stressed plant sample

\section{Mineral element analyses}

At the end of $25^{\text {th }}, 30^{\text {th }}, 35^{\text {th }}$ and $40^{\text {th }}$ days after sowing, representative control and low temperature stress-treated plants were harvested, the shoot were initially dried at open places for two days and then dried in an oven at $65{ }^{\circ} \mathrm{C}$ for $48 \mathrm{~h}$. About $200 \mathrm{mg}$ of 
dry shoot samples were ground and subjected to pre-digestion in ethyl alcohol and then burned to ash in an ash oven at $550{ }^{\circ} \mathrm{C}$. Resultant ash was dissolved in $3.3 \% \mathrm{HCl}$, filtered through blue-band filter paper. $\mathrm{K}, \mathrm{Ca}$ and $\mathrm{Mg}$ readings were performed in an atomic absorption device at Scientific Research and Implementation Center of Yüzüncü Y1l University (Kacar, 1994; Kacar and İnal, 2008).

\section{Lipid peroxidation}

Lipid peroxidation of the plants generally expressed as malondialdehyde (MDA) content. About $0.5 \mathrm{~g}$ leaf sample was homogenized in $10 \mathrm{ml} 0.1 \%$ trichloric acid (TCA) and resultant homogenate was centrifuged at $15000 \mathrm{rpm}$ for $5 \mathrm{~min}$. About $1 \mathrm{ml}$ was taken from the clear portion of the centrifuged sample and supplemented with $0,5 \%$ tiobarbituric acid (TBA) dissolved in $4 \mathrm{ml} 20 \%$ TCA. The mixture was kept at $95{ }^{\circ} \mathrm{C}$ for $30 \mathrm{~min}$ and instantly cooled in ice-bath. Cooled sample was then centrifuged at $10000 \mathrm{rpm}$ for $10 \mathrm{~min}$ and absorbance readings were performed in clear portion at 532 and $600 \mathrm{~nm}$ wave lengths. The following equation was used to calculate malondialdehyde (MDA) content of the samples (Heath and Packer, 1968; Sairam and Saxena, 2000):

$$
\operatorname{MDA}(\mathrm{nmol} \mathrm{ml}-1)=[(\mathrm{A} 532-\mathrm{A} 600) / 155000] 10^{6}
$$

\section{Antioxidative enzyme analyses}

About $1 \mathrm{~g}$ frozen leaf sample was homogenized in $5 \mathrm{ml}$ cold $0.1 \mathrm{M}$ Na-phosphate, $0.5 \mathrm{mM}$ Na-EDTA and $1 \mathrm{mM}$ ascorbic acid mixture (pH: 7.5) and the resultant homogenate was centrifuged at $18000 \mathrm{rpm}$ and $4{ }^{\circ} \mathrm{C}$ for $30 \mathrm{~min}$. Ascorbate peroxidase (AP) activity of the resultant homogenate was instantly determined. For catalase (CAT) and superoxide dismutase (SOD) activities, $1 \mathrm{~g}$ frozen leaf sample was homogenized in $5 \mathrm{ml}$ cold $0.1 \mathrm{M}$ Na-phosphate and $0.5 \mathrm{mM}$ Na-EDTA mixture (pH: 7.5). Resultant homogenate was centrifuged at $18000 \mathrm{rpm}$ and $4{ }^{\circ} \mathrm{C}$ for $30 \mathrm{~min}$. A portion of homogenate was used to determine CAT activity instantly and the remaining portion was kept at $-20{ }^{\circ} \mathrm{C}$ for SOD activity (Jebara et al., 2005; Bagc1, 2010).

\section{Catalase (CAT) activity}

Catalase activity was determined through monitoring the inhibition of $\mathrm{H}_{2} \mathrm{O}_{2}$ at $240 \mathrm{~nm}$. As the reaction solution, $0.05 \mathrm{M}$ phosphate buffer $\left(\mathrm{KH}_{2} \mathrm{PO}_{4}\right)$ and $1.5 \mathrm{mM} \mathrm{H}_{2} \mathrm{O}_{2}$ mixture was used (pH: 7.0). About $2.5 \mathrm{ml}$ reaction solution was mixed with $0.2 \mathrm{ml}$ plant extract. Readings were performed in a spectrophotometer at 0 and 60th seconds. Reaction was initiated with the addition of $0.1 \mathrm{ml}$ enzyme extract. Assessments were made by taking the change in absorbance within a minute into consideration (Jebara et al., 2005; Bagc1, 2010).

\section{Superoxide dismutase (SOD) activity}

SOD activity was determined through monitoring te inhibition of nitroblue tetrazolium (NBT) at $560 \mathrm{~nm}$ wave length. As a reaction solution, $50 \mathrm{mM}$ Na-phosphate buffer $\left(\mathrm{Na}_{2} \mathrm{HPO}_{4} \times \mathrm{H}_{2} \mathrm{O}_{2}\right), 0.1 \mathrm{mM}$ Na- EDTA, $33 \mu \mathrm{M}$ NBT, $5 \mu \mathrm{M}$ riboflavin and $13 \mathrm{mM}$ methionine mixture was used ( $\mathrm{pH}: 7.0)$. About $2.5 \mathrm{ml}$ reaction solution was mixed with 0.1 or $0.2 \mathrm{ml}$ plant extract. Reaction was performed by keeping at $25{ }^{\circ} \mathrm{C}$ 
under $75 \mu \mathrm{mol} \mathrm{m}-2 \mathrm{~s}-1(40 \mathrm{~W})$ light for $10 \mathrm{~min}$. Control solution without enzyme supplementation was kept at dark for the same duration. Readings were performed in control and reaction solution at $560 \mathrm{~nm}$. SOD activity was identified as the activity reducing 50\% of NTB (Rahnama and Ebrahimzadeh, 2005).

\section{Ascorbate peroxidase (APX) activity}

Ascorbate peroxidase (APX) activity was measured through ascorbic acid-induced inhibition of $\mathrm{H}_{2} \mathrm{O}_{2}$ at $290 \mathrm{~nm}$. As the reaction solution, $50 \mathrm{mM}$ phosphate buffer $\left(\mathrm{KH}_{2} \mathrm{PO}_{4}\right), 0.5 \mathrm{mM}$ ascorbic acid, $0.1 \mathrm{mM}$ EDTA and $1.5 \mathrm{mM} \mathrm{H}_{2} \mathrm{O}_{2}$ mixture was used (pH: 7.0). About $3 \mathrm{ml}$ reaction solution was mixed with $0.1 \mathrm{ml}$ plant extract. Readings were performed in a spectrophotometer at $290 \mathrm{~nm}$ in 0 and $60^{\text {th }}$ seconds. Reaction was initiated with $0.1 \mathrm{ml}$ enzyme addition. Assessments were made by taking the changes in absorbance within a minute into consideration (Sairam et al., 2005).

\section{Chlorophyll}

$0.25 \mathrm{~g}$ samples from the third leaf of the plant were homogenized in $80 \%$ acetone in a place where the light does not directly come out, then the extract completed to $25 \mathrm{ml}$ with acetone after filtering. Prepared samples were read at $663 \mathrm{~nm}$ and $645 \mathrm{~nm}$ wavelength and calculated by the following formula ((Lichtenthaler, 1983; Amira, 2011).

$$
\begin{aligned}
& \text { Chlorophyll a }(\mathrm{mg} / \mathrm{g})=(12.7 * 663 \mathrm{~nm})-(2.69 * 645 \mathrm{~nm}) * \mathrm{~V} / \mathrm{W} * 10000 \\
& \text { Chlorophyll b }(\mathrm{mg} / \mathrm{g})=(22.91 * 645 \mathrm{~nm})-(4.68 * 663 \mathrm{~nm}) * \mathrm{~V} / \mathrm{W}^{*} 10000 \\
& \text { Total Chlorophyll }=\text { Chlorophyll a }+ \text { Chlorophyll b }
\end{aligned}
$$

\section{Statistical analysis}

Experiments were conducted in randomized plots - factorial experimental design. Experimental data were subjected to variance analysis and significant means were compared with Duncan's multiple range test (Yesilova and Denizhan, 2016). Statistical analyses were performed by using SAS 9.4 software (SAS, 2018).

\section{Results}

In the present study, quite significant differences were observed between the control plants and cold stress-treated plants. Cold stress reduced chlorophyll a, chlorophyll-b and total chlorophyll contents and such decreases were greater in sensitive genotypes than in tolerant genotypes (Tables 1-3). Under low temperature stress, the greatest chlorophyll a, chlorophyll-b and total chlorophyll contents were obtained from the $1^{\text {st }}$ period of Ç30 common bean genotype (chlorophyll-a: $0.468 \mathrm{mg} \mathrm{g}^{-1} \mathrm{FW}$, chlorophyll-b: $0.188 \mathrm{mg} \mathrm{g}^{-1} \mathrm{FW}$, and total chlorophyll: $0.657 \mathrm{mg} \mathrm{g}^{-1} \mathrm{FW}$ ) and the lowest chlorophyll-a (0.206 $\left.\mathrm{mg} \mathrm{g}^{-1} \mathrm{FW}\right)$, chlorophyll-b $\left(0.106 \mathrm{mg} \mathrm{g}^{-1} \mathrm{FW}\right)$ and total chlorophyll content $\left(0.312 \mathrm{mg} \mathrm{g}^{-1} \mathrm{FW}\right)$ were obtained from the $4^{\text {th }}$ period of Ç13 genotype (Tables $\left.1-3\right)$. Considering the effects of low temperature on total chlorophyll content, the greatest total chlorophyll content of $0.697 \mathrm{mg} \mathrm{g}^{-1} \mathrm{FW}$ in the $1^{\text {st }}$ period of low temperaturetolerant Ç30 bean genotype decreased to $0.578 \mathrm{mg} \mathrm{g}^{-1} \mathrm{FW}$ in the $2^{\text {nd }}$ period and 
decreased to $0.481 \mathrm{mg} \mathrm{g}^{-1} \mathrm{FW}$ in the $4^{\text {th }}$ period. In Yakutiye (Y) bean cultivar, total chlorophyll content of $0.616 \mathrm{mg} \mathrm{g}^{-1} \mathrm{FW}$ in the $1^{\text {st }}$ period decreased to $0.581 \mathrm{mg} \mathrm{g}^{-1} \mathrm{FW}$ in the $2^{\text {nd }}$ period and decreased to $0.460 \mathrm{mg} \mathrm{g}^{-1} \mathrm{FW}$ in the $4^{\text {th }}$ period. On the other hand, in low temperature-sensitive Ç13 bean genotype, total chlorophyll content of $0.633 \mathrm{mg} \mathrm{g}^{-1} \mathrm{FW}$ in the $1^{\text {st }}$ period decreased to $0.582 \mathrm{mg} \mathrm{g}^{-1} \mathrm{FW}$ in the $2^{\text {nd }}$ period and decreased to $0.312 \mathrm{mg} \mathrm{g}^{-1} \mathrm{FW}$ in the $4^{\text {th }}$ period. In low temperature-sensitive Zulbiye (Z) bean cultivar, total chlorophyll content of $0.631 \mathrm{mg} \mathrm{g}^{-1} \mathrm{FW}$ in the $1^{\text {st }}$ period decreased to $0.563 \mathrm{mg} \mathrm{g}^{-1} \mathrm{FW}$ in the $2^{\text {nd }}$ period and decreased to $0.326 \mathrm{mg} \mathrm{g}^{-1} \mathrm{FW}$ in the $4^{\text {th }}$ period (Table 3). In control plants, chlorophyll a, chlorophyll b and total chlorophyll contents increased in all 4 periods. The period-dependent differences in chlorophyll contents of the control and low temperature treatments were found to be significant (Table 4). Chlorophyll $\mathrm{a}+\mathrm{b}$ values of the control treatments were identified as $0.731 \mathrm{mg} \mathrm{g}^{-1} \mathrm{FW}$ for Ç30, $0.734 \mathrm{mg} \mathrm{g}^{-1} \mathrm{FW}$ for Ç13, $0.727 \mathrm{mg} \mathrm{g}^{-1} \mathrm{FW}$ for Yakutiye and $0.653 \mathrm{mg} \mathrm{g}^{-1} \mathrm{FW}$ for Zulbiye. Chlorophyll $\mathrm{a}+\mathrm{b}$ values of the low temperature treatments were identified as $0.562 \mathrm{mg} \mathrm{g}^{-1} \mathrm{FW}$ for Ç30, $0.482 \mathrm{mg} \mathrm{g}^{-1} \mathrm{FW}$ for Ç13, $0.541 \mathrm{mg} \mathrm{g}^{-1}$ FW for Yakutiye and $0.475 \mathrm{mg} \mathrm{g}^{-1} \mathrm{FW}$ for Zulbiye (Table 4).

Table 1. Change in chlorophyll a $\left(\mathrm{mg}^{-1} \mathrm{FW}\right)$ content of common bean genotypes under low temperature stress in 4 periods

\begin{tabular}{ccccc}
\hline Genotype & $\begin{array}{c}\text { Period 1 } \\
\left(\text { day 25 }^{\text {th }}\right)\end{array}$ & $\begin{array}{c}\text { Period 2 } \\
\left(\text { day 30 }^{\text {th }}\right)\end{array}$ & $\begin{array}{c}\text { Period 3 } \\
\left.\text { (day 35 }^{\text {th }}\right)\end{array}$ & $\begin{array}{c}\text { Period 4 } \\
\left.\text { (day 40 }^{\text {th }}\right)\end{array}$ \\
\hline Control & & & \\
Ç30 & $0.485 \mathrm{~d}^{*}$ & $0.472 \mathrm{de}$ & $0.508 \mathrm{c}$ & $0.535 \mathrm{ab}$ \\
Yakutiye & $0.460 \mathrm{ef}$ & $0.480 \mathrm{~d}$ & $0.514 \mathrm{c}$ & $0.534 \mathrm{ab}$ \\
Ç13 & $0.455 \mathrm{eg}$ & $0.472 \mathrm{de}$ & $0.522 \mathrm{bc}$ & $0.541 \mathrm{a}$ \\
Zulbiye & 0.3561 & $0.418 \mathrm{~h}$ & 0.439 & $0.446 \mathrm{fg}$ \\
\hline Low temperatures & & & \\
Ç30 & $0.468 \mathrm{a}^{*}$ & $0.412 \mathrm{~d}$ & $0.378 \mathrm{e}$ & $0.337 \mathrm{~g}$ \\
Yakutiye & $0.439 \mathrm{~b}$ & $0.424 \mathrm{~cd}$ & $0.362 \mathrm{f}$ & $0.326 \mathrm{~g}$ \\
Ç13 & $0.458 \mathrm{a}$ & $0.434 \mathrm{bc}$ & $0.276 \mathrm{~h}$ & $0.206 \mathrm{j}$ \\
Zulbiye & $0.456 \mathrm{a}$ & $0.416 \mathrm{~d}$ & 0.2551 & $0.217 \mathrm{j}$ \\
\hline
\end{tabular}

* Means in control and low temperature followed by the same letter are not significantly different $(\mathrm{P}<0.05)$

Table 2. Change in chlorophyll $b\left(\mathrm{mg}^{-1} \mathrm{FW}\right)$ content of bean (Phaseolus vulgaris) genotypes under low temperature stress in 4 periods

\begin{tabular}{c|c|c|c|c}
\hline Genotype & $\begin{array}{c}\text { Period 1 } \\
\left(\text { day 25 }^{\text {th }}\right)\end{array}$ & $\begin{array}{c}\text { Period 2 } \\
\left(\text { day 30 }^{\text {th }}\right)\end{array}$ & $\begin{array}{c}\text { Period 3 } \\
\left(\text { day 35 }^{\text {th }}\right)\end{array}$ & $\begin{array}{c}\text { Period 4 } \\
\left(\text { day 40 }^{\text {th }}\right)\end{array}$ \\
\hline Control & & & \\
Ç30 & $0.212 \mathrm{~g}^{*}$ & $0.224 \mathrm{ef}$ & $0.234 \mathrm{~cd}$ & $0.251 \mathrm{a}$ \\
Yakutiye & $0.209 \mathrm{~g}$ & $0.221 \mathrm{f}$ & $0.241 \mathrm{bc}$ & $0.249 \mathrm{ab}$ \\
Ç13 & $0.223 \mathrm{f}$ & $0.232 \mathrm{ce}$ & $0.243 \mathrm{ab}$ & $0.247 \mathrm{ab}$ \\
Zulbiye & $0.233 \mathrm{ce}$ & $0.228 \mathrm{df}$ & $0.243 \mathrm{ab}$ & $0.246 \mathrm{ab}$ \\
\hline Low temperatures & & & \\
Ç30 & $0.188 \mathrm{a}^{*}$ & $0.168 \mathrm{c}$ & $0.149 \mathrm{de}$ & $0.143 \mathrm{e}$ \\
Yakutiye & $0.176 \mathrm{~b}$ & $0.154 \mathrm{~d}$ & $0.148 \mathrm{de}$ & $0.134 \mathrm{f}$ \\
Ç13 & $0.176 \mathrm{~b}$ & $0.147 \mathrm{de}$ & $0.124 \mathrm{~g}$ & $0.106 \mathrm{~h}$ \\
Zulbiye & $0.175 \mathrm{~b}$ & $0.147 \mathrm{de}$ & $0.125 \mathrm{~g}$ & $0.108 \mathrm{~h}$ \\
\hline
\end{tabular}

*Means in control and low temperature followed by the same letter are not significantly different $(\mathrm{P}<0.05)$ 
Table 3. Change in chlorophyll $a+b\left(\mathrm{mg}^{-1} \mathrm{FW}\right)$ content of bean (Phaseolus vulgaris) genotypes under low temperature stress in 4 periods

\begin{tabular}{c|c|c|c|c}
\hline Genotype & $\begin{array}{c}\text { Period 1 } \\
\left(\text { day 25 }^{\text {th }}\right)\end{array}$ & $\begin{array}{c}\text { Period 2 } \\
(\text { day 30 }\end{array}$ & $\begin{array}{c}\text { Period 3 } \\
\left(\text { day 35 }^{\text {th }}\right)\end{array}$ & $\begin{array}{c}\text { Period 4 } \\
\left(\text { day 40 }^{\text {th }}\right)\end{array}$ \\
\hline Control & & & \\
Ç30 & $0.697 \mathrm{de} *$ & $0.696 \mathrm{df}$ & $0.742 \mathrm{c}$ & $0.787 \mathrm{a}$ \\
Yakutiye & $0.669 \mathrm{~g}$ & $0.701 \mathrm{de}$ & $0.756 \mathrm{bc}$ & $0.784 \mathrm{a}$ \\
Ç13 & $0.678 \mathrm{fg}$ & $0.705 \mathrm{~d}$ & $0.765 \mathrm{~b}$ & $0.788 \mathrm{a}$ \\
Zulbiye & $0.589 \mathrm{1}$ & $0.647 \mathrm{~h}$ & $0.682 \mathrm{eg}$ & $0.693 \mathrm{df}$ \\
\hline Low temperatures & & & \\
Ç30 & $0.657 \mathrm{a}^{*}$ & $0.581 \mathrm{~d}$ & $0.528 \mathrm{f}$ & $0.481 \mathrm{~h}$ \\
Yakutiye & $0.616 \mathrm{c}$ & $0.578 \mathrm{~d}$ & $0.511 \mathrm{~g}$ & 0.4601 \\
Ç13 & $0.633 \mathrm{~b}$ & $0.582 \mathrm{~d}$ & $0.401 \mathrm{j}$ & $0.312 \mathrm{~m}$ \\
Zulbiye & $0.631 \mathrm{~b}$ & $0.563 \mathrm{e}$ & $0.379 \mathrm{k}$ & 0.3261 \\
\hline
\end{tabular}

*Means in control and low temperature followed by the same letter are not significantly different $(\mathrm{P}<0.05)$

Table 4. Change in chlorophyll $a, b$ and chlorophyll $a+b$ content of control and low temperature stress treatments

\begin{tabular}{c|c|c|c|c|c|c}
\hline \multirow{2}{*}{ Genotype } & \multicolumn{2}{|c|}{ Chlorophyll a } & \multicolumn{2}{c|}{ Chlorophyll b } & \multicolumn{2}{c}{ Chlorophyll a+b } \\
\cline { 2 - 7 } & Control & $\begin{array}{c}\text { Low } \\
\text { temperatures }\end{array}$ & Control & $\begin{array}{c}\text { Low } \\
\text { temperatures }\end{array}$ & Control & $\begin{array}{c}\text { Low } \\
\text { temperatures }\end{array}$ \\
\hline Ç30 & $0.439 \mathrm{~d}^{*}$ & $0.399 \mathrm{a}^{*}$ & $0.230 \mathrm{~b}^{*}$ & $0.162 \mathrm{a}^{*}$ & $0.731 \mathrm{a}^{*}$ & $0.562 \mathrm{a}^{*}$ \\
Yakutiye & $0.461 \mathrm{c}$ & $0.388 \mathrm{~b}$ & $0.230 \mathrm{~b}$ & $0.154 \mathrm{~b}$ & $0.727 \mathrm{a}$ & $0.541 \mathrm{~b}$ \\
Ç13 & $0.496 \mathrm{~b}$ & $0.343 \mathrm{c}$ & $0.237 \mathrm{a}$ & $0.138 \mathrm{c}$ & $0.734 \mathrm{a}$ & $0.482 \mathrm{c}$ \\
Zulbiye & $0.514 \mathrm{a}$ & $0.336 \mathrm{~d}$ & $0.238 \mathrm{a}$ & $0.139 \mathrm{c}$ & $0.653 \mathrm{~b}$ & $0.475 \mathrm{c}$ \\
\hline
\end{tabular}

*Means in each column followed by the same letter are not significantly different $(\mathrm{P}<0.05)$

There were differences in ion contents of the $1^{\text {st }}$ and the $4^{\text {th }}$ period and $\mathrm{K}, \mathrm{Ca}$ and $\mathrm{Mg}$ contents decreased at the end of $4^{\text {th }}$ period as compared to the $1^{\text {st }}$ period. Such decreases were greater in low temperature sensitive bean plants (Tables 5-7). Under low temperature stress, the greatest $\mathrm{K}$ content $(1.530 \%)$ was obtained from the $1^{\text {st }}$ period of Zulbiye been genotype and the lowest $\mathrm{K}$ content $(1.170 \%)$ was obtained from the $4^{\text {th }}$ period of Ç13 bean genotype. The greatest Ca content $(3.365 \%)$ was obtained from the $1^{\text {st }}$ period of Zulbiye bean genotype and the lowest Ca content $(1.645 \%)$ was obtained from the $4^{\text {th }}$ period of Zulbiye bean genotype. The greatest $\mathrm{Mg}$ content $(0.410 \%)$ was obtained from the $1^{\text {st }}$ period of Zulbiye bean genotype, the lowest $\mathrm{Mg}$ content was obtained from the $4^{\text {th }}$ period of again Zulbiye bean genotype (Tables 6-7).

As compared to the $1^{\text {st }}$ period, plant $\mathrm{K}, \mathrm{Ca}$ and $\mathrm{Mg}$ ion contents of the control groups increased at the end the $4^{\text {th }}$ period. The K contents of Ç30, Yakutiye, Zulbiye and Ç13 genotypes were found to be significant under low temperature stress. The $\mathrm{K}$ content of $1.467 \%$ in the $1^{\text {st }}$ period of Ç30 genotype decreased to $1.420 \%$ in the $2^{\text {nd }}$ period, but placed in the same statistical group as Yakutiye (Y) cultivar with a K value of $1.442 \%$. $\mathrm{K}$ contents also decreased in the $3^{\text {rd }}$ and $4^{\text {th }}$ periods, Ç30 and Zulbiye (Z) bean cultivar were placed in the same statistical group. K content of Ç30 bean genotype decreased to 
$1.263 \%$ in the $4^{\text {th }}$ period and $\mathrm{K}$ content of Zulbiye cultivar of the same statistical group decreased to $1.275 \%$. The decreases in $\mathrm{K}$ content of Yakutiye bean cultivar in the $2^{\text {nd }}$ and $3^{\text {rd }}$ periods were not found to be significant (Table 5).

Table 5. Change in potassium (K) content (\%) of common bean genotypes under low temperature stress in 4 periods

\begin{tabular}{c|c|c|c|c}
\hline Genotype & $\begin{array}{c}\text { Period 1 } \\
\left(\text { day 25 }^{\text {th }}\right)\end{array}$ & $\begin{array}{c}\text { Period 2 } \\
\left(\text { day 30 }^{\text {th }}\right)\end{array}$ & $\begin{array}{c}\text { Period 3 } \\
\left(\text { day 35 }^{\text {th }}\right)\end{array}$ & $\begin{array}{c}\text { Period 4 } \\
\left.\text { (day 40 }^{\text {th }}\right)\end{array}$ \\
\hline Control & & & \\
Ç30 & $3.370 \mathrm{c}^{*}$ & $3.382 \mathrm{c}$ & $3.407 \mathrm{~b}$ & $3.44 \mathrm{a}$. \\
Yakutiye & $3.265 \mathrm{fg}$ & $3.282 \mathrm{ef}$ & $3.292 \mathrm{e}$ & $3.30 \mathrm{e}$ \\
Ç13 & $3.337 \mathrm{~d}$ & $3.365 \mathrm{c}$ & $3.265 \mathrm{fg}$ & $3.415 \mathrm{~b}$ \\
Zulbiye & $3.222 \mathrm{r}$ & $3.132 \mathrm{j}$ & $3.237 \mathrm{~h} \mathrm{~h}$ & $3.257 \mathrm{gh}$ \\
\hline Low temperatures & & & \\
Ç30 & $1.467 \mathrm{c}^{*}$ & $1.420 \mathrm{~d}$ & $1.335 \mathrm{f}$ & $1.263 \mathrm{~g}$ \\
Yakutiye & $1.530 \mathrm{~b}$ & $1.442 \mathrm{~d}$ & $1.425 \mathrm{~d}$ & $1.335 \mathrm{f}$ \\
Ç13 & $1.422 \mathrm{~d}$ & $1.367 \mathrm{e}$ & $1.232 \mathrm{~h}$ & $1.170 \mathrm{1}$ \\
Zulbiye & $1.567 \mathrm{a}$ & $1.510 \mathrm{~b}$ & $1.263 \mathrm{~g}$ & $1.275 \mathrm{~g}$ \\
\hline
\end{tabular}

*Means in control and low temperature followed by the same letter are not significantly different $(\mathrm{P}<0.05)$

With regard to $\mathrm{Ca}$ content of bean genotypes under low temperature stress, Ç30 genotype and Yakutiye (Y) bean cultivar were placed in the same statistical group in the $1^{\text {st }}$ period of stress (Ç30: 3.475\%; Y: 3.502\%). Ç13 genotype and Zulbiye (Z) bean cultivar were also placed in the same statistical group (Ç13: 3.665\%; Z: 3.647\%). There were decreases in $\mathrm{Ca}$ contents of the bean genotypes also in the $2^{\text {nd }}$ period of the low temperature stress. Ç30, Ç13 and Yakutiye bean genotypes were placed in the same statistical group. As compared to the 1 st and $2^{\text {nd }}$ periods, Ca contents decreased in the $3^{\text {rd }}$ period (Ç30: $2.842 \%$; Y: 3.357\%; Ç13: $\left.2.900 \% ; \mathrm{Z}: 2.695 \%\right)$ and in the $4^{\text {th }}$ period (Ç30: 2.635\%; Y: 2.785\%; Ç13: 1.865\%; Z: 1.645\%) (Table 6).

Table 6. Change in calcium (Ca) content (\%) of bean (Phaseolus vulgaris) genotypes under low temperature stress in 4 periods

\begin{tabular}{|c|c|c|c|c|}
\hline Genotype & $\begin{array}{c}\text { Period 1 } \\
\left(\text { day } 25^{\text {th }}\right)\end{array}$ & $\begin{array}{c}\text { Period 2 } \\
(\text { day 30 }\end{array}$ & $\begin{array}{c}\text { Period 3 } \\
(\text { day 35 } \\
\text { th })\end{array}$ & $\begin{array}{c}\text { Period } 4 \\
\left(\text { day } 40^{\text {th }}\right)\end{array}$ \\
\hline \multicolumn{5}{|l|}{ Control } \\
\hline Ç30 & 3.562hi* & $3.512 \mathrm{k}$ & $3.612 \mathrm{e}$ & $3.657 \mathrm{~cd}$ \\
\hline Yakutiye & $3.640 \mathrm{~d}$ & $3.677 \mathrm{c}$ & $3.705 b$ & $3.522 \mathrm{jk}$ \\
\hline Ç13 & $3.583 \mathrm{fh}$ & $3.573 \mathrm{gh}$ & $3.542 \mathrm{ij}$ & $3.593 \mathrm{eg}$ \\
\hline Zulbiye & $3.603 \mathrm{ef}$ & $3.750 \mathrm{a}$ & $3.575 \mathrm{gh}$ & 3.4621 \\
\hline \multicolumn{5}{|c|}{ Low temperatures } \\
\hline Ç30 & $3.475 \mathrm{ac}^{*}$ & $3.405 \mathrm{bc}$ & $2.842 \mathrm{de}$ & $2.635 f$ \\
\hline Yakutiye & $3.502 \mathrm{ac}$ & $3.400 \mathrm{bc}$ & $3.357 \mathrm{c}$ & $2.785 \mathrm{df}$ \\
\hline Ç13 & $3.665 \mathrm{a}$ & $3.565 \mathrm{ab}$ & $2.900 \mathrm{~d}$ & $1.865 \mathrm{~g}$ \\
\hline Zulbiye & $3.647 \mathrm{a}$ & $3.400 \mathrm{bc}$ & $2.695 \mathrm{ef}$ & $1.645 \mathrm{~h}$ \\
\hline
\end{tabular}

*Means in control and low temperature followed by the same letter are not significantly different $(\mathrm{P}<0.05)$ 
While the differences in magnesium $(\mathrm{Mg})$ contents of Ç30, Y and $\mathrm{Z}$ bean (Phaseolus vulgaris) genotypes were not found to be significant in the $1^{\text {st }}$ period (Ç30: $0.362 \%$; Y: $0.380 \% ; \mathrm{Z}: 0.382 \%$ ) and in the $2^{\text {nd }}$ period (Ç30: $0.262 \%$; Y: $0.280 \% ; \mathrm{Z}: 0.285 \%$ ) and they were placed in the same statistical group, but Ç13 genotype was found to be significantly different from the other groups. Magnesium content of genotypes decreased in the $3^{\text {rd }}$ period, but all genotypes were placed in the same statistical group. In the $4^{\text {th }}$ period of low temperature stress, decrease in Mg contents of Ç30, Ç13 and Y bean (Phaseolus vulgaris) genotypes (Ç30: 0.195\%; Y: 0.195\%; Ç13: 0.190\%) were not found to be significant and they were all placed in the same statistical group, but Zulbiye $(\mathrm{Z})$ bean genotype with an $\mathrm{Mg}$ content of $0.182 \%$ was found to be significantly different from the other genotypes (Table 7). Period-dependent differences in $\mathrm{K}, \mathrm{Ca}$ and $\mathrm{Mg}$ contents of control and low temperature treatments were found to be significant (Table 8). K contents of control groups were identified as Ç30: 3.41\%, Ç13: $3.34 \%$, Yakutiye: $3.29 \%$ and Zulbiye: $3.21 \%$ and $\mathrm{K}$ contents of low temperature treatments were identified as Ç30: $1.37 \%$, Ç13: 1.29\%, Yakutiye: $1.43 \%$ and Zulbiye: $1.40 \%$ (Table 8).

Table 7. Change in magnesium (Mg) content (\%) of bean (Phaseolus vulgaris) genotypes under low temperature stress in 4 periods

\begin{tabular}{|c|c|c|c|c|}
\hline Genotype & $\begin{array}{c}\text { Period } 1 \\
\left(\text { day } 25^{\text {th }}\right)\end{array}$ & $\begin{array}{c}\text { Period } 2 \\
(\text { day 30 } \\
\end{array}$ & $\begin{array}{c}\text { Period 3 } \\
\left(\text { day } 35^{\text {th }}\right) \\
\end{array}$ & $\begin{array}{r}\text { Period } 4 \\
\left(\text { day } 40^{\text {th }}\right)\end{array}$ \\
\hline \multicolumn{5}{|l|}{ Control } \\
\hline Ç30 & $0.407 \mathrm{dh} *$ & $0.435 \mathrm{ce}$ & $0.510 \mathrm{a}$ & $0.382 \mathrm{fh}$ \\
\hline Yakutiye & $0.385 \mathrm{eh}$ & $0.422 \mathrm{df}$ & $0.500 \mathrm{a}$ & $0.365 \mathrm{~h}$ \\
\hline Ç13 & $0.397 \mathrm{dh}$ & $0.447 \mathrm{bd}$ & $0.475 \mathrm{ac}$ & $0.390 \mathrm{eh}$ \\
\hline Zulbiye & $0.367 \mathrm{gh}$ & $0.417 \mathrm{dg}$ & $0.485 \mathrm{ab}$ & 0.3051 \\
\hline \multicolumn{5}{|c|}{ Low temperatures } \\
\hline Ç30 & $0.362 b^{*}$ & $0.262 \mathrm{~d}$ & $0.227 \mathrm{e}$ & $0.195 f$ \\
\hline Yakutiye & $0.380 \mathrm{~b}$ & $0.280 \mathrm{~d}$ & $0.230 \mathrm{e}$ & $0.195 f$ \\
\hline Ç13 & $0.410 \mathrm{a}$ & $0.310 \mathrm{c}$ & $0.222 \mathrm{e}$ & $0.190 \mathrm{f}$ \\
\hline Zulbiye & $0.385 b$ & $0.285 \mathrm{~d}$ & $0.237 \mathrm{e}$ & $0.185 f$ \\
\hline
\end{tabular}

*Means in control and low temperature followed by the same letter are not significantly different $(\mathrm{P}<0.05)$

Table 8. Change in $\mathrm{K}(\%), \mathrm{Ca}(\%)$ and $\mathrm{Mg}(\%)$ content of control and low temperature stress treatments

\begin{tabular}{c|c|c|c|c|c|c}
\hline Genotype & \multicolumn{2}{|c|}{ K } & \multicolumn{2}{c|}{ Ca } & \multicolumn{2}{c}{ Mg } \\
\hline & Control & $\begin{array}{c}\text { Low } \\
\text { temperatures }\end{array}$ & Control & $\begin{array}{c}\text { Low } \\
\text { temperatures }\end{array}$ & Control & $\begin{array}{c}\text { Low } \\
\text { temperatures }\end{array}$ \\
\hline Ç30 & $3.41 \mathrm{a}^{*}$ & $1.37 \mathrm{c}^{*}$ & $3.59 \mathrm{~b}^{*}$ & $3.09 \mathrm{~b}^{*}$ & $0.433 \mathrm{ac} *$ & $0.261 \mathrm{~b}^{*}$ \\
Yakutiye & $3.29 \mathrm{c}$ & $1.43 \mathrm{a}$ & $3.63 \mathrm{a}$ & $3.26 \mathrm{a}$ & $0.418 \mathrm{a}$ & $0.271 \mathrm{~b}$ \\
Ç13 & $3.34 \mathrm{~b}$ & $1.29 \mathrm{~d}$ & $3.57 \mathrm{c}$ & $2.99 \mathrm{c}$ & $0.427 \mathrm{a}$ & $0.283 \mathrm{a}$ \\
Zulbiye & $3.21 \mathrm{~d}$ & $1.40 \mathrm{~b}$ & $3.59 \mathrm{~b}$ & $2.85 \mathrm{~d}$ & $0.393 \mathrm{~b}$ & $0.273 \mathrm{ab}$ \\
\hline
\end{tabular}

*Means in each column followed by the same letter are not significantly different $(\mathrm{P}<0.05)$ 
Significant differences were observed in MDA contents of the bean plants in 4 periods and increases were observed at the end of $4^{\text {th }}$ period as compared to the 1 st period. Such increases were greater in low temperature sensitive bean genotypes (Table 9). Similar changes were also observed in CAT, SOD and APX antioxidative enzyme activities. Increases were observed in CAT, SOD and APX activities of the bean genotypes in 4 periods. Increases were greater in the $4^{\text {th }}$ period as compared to the $1^{\text {st }}$ period and increases were also greater in low temperature-sensitive bean genotypes (Tables 10-13).

Table 9. Change in malondialdehyde (MDA nmol $g^{-1} F W$ ) content of bean (Phaseolus vulgaris) genotypes under low temperature stress in 4 periods

\begin{tabular}{c|c|c|c|c}
\hline Genotype & $\begin{array}{c}\text { Period 1 } \\
\left(\text { day 25 }^{\text {th }}\right)\end{array}$ & $\begin{array}{c}\text { Period 2 } \\
\left(\text { day 30 }^{\text {th }}\right)\end{array}$ & $\begin{array}{c}\text { Period 3 } \\
\left(\text { day 35 }^{\text {th }}\right)\end{array}$ & $\begin{array}{c}\text { Period 4 } \\
\left(\text { day 40 }^{\text {th }}\right)\end{array}$ \\
\hline Control & & & \\
Ç30 & $5.662 \mathrm{~b}^{*}$ & $5.663 \mathrm{~b}$ & $5.713 \mathrm{ab}$ & $5.735 \mathrm{ab}$. \\
Yakutiye & $5.691 \mathrm{~b}$ & $5.643 \mathrm{~b}$ & $5.719 \mathrm{ab}$ & $5.732 \mathrm{ab}$ \\
Ç13 & $5.634 \mathrm{~b}$ & $5.899 \mathrm{a}$ & $5.786 \mathrm{ab}$ & $5.813 \mathrm{ab}$ \\
Zulbiye & $5.662 \mathrm{~b}$ & $5.615 \mathrm{~b}$ & $5.767 \mathrm{ab}$ & $5.799 \mathrm{ab}$ \\
\hline Low temperatures & & & \\
Ç30 & $5.6131^{*}$ & $5.925 \mathrm{~h}$ & $5.954 \mathrm{~g}$ & $6.106 \mathrm{e}$ \\
Yakutiye & $5.685 \mathrm{j}$ & 5.8811 & $5.981 \mathrm{~g}$ & $6.114 \mathrm{e}$ \\
Ç13 & $5.646 \mathrm{k}$ & $6.057 \mathrm{f}$ & $6.249 \mathrm{c}$ & $6.325 \mathrm{~b}$ \\
Zulbiye & $5.668 \mathrm{jk}$ & $6.217 \mathrm{~d}$ & $6.255 \mathrm{c}$ & $6.373 \mathrm{a}$ \\
\hline
\end{tabular}

*Means in control and low temperature followed by the same letter are not significantly different $(\mathrm{P}<0.05)$

Table 10. Change in superoxide dismutase (SOD unit $g^{-1} F W$ ) content of bean (Phaseolus vulgaris) genotypes under low temperature stress in 4 periods

\begin{tabular}{|c|c|c|c|c|}
\hline Genotype & $\begin{array}{c}\text { Period 1 } \\
\left({\left.\text { day } 25^{\text {th }}\right)}^{-}\right.\end{array}$ & $\begin{array}{c}\text { Period } 2 \\
\left(\text { day } 30^{\text {th }}\right)\end{array}$ & $\begin{array}{c}\text { Period 3 } \\
\left(\text { day } 35^{\text {th }}\right)\end{array}$ & $\begin{array}{r}\text { Period } 4 \\
\left(\text { day } 40^{\text {th }}\right)\end{array}$ \\
\hline \multicolumn{5}{|l|}{ Control } \\
\hline Ç30 & $105.025 \mathrm{fh} *$ & $107.158 \mathrm{cg}$ & $109.449 \mathrm{c}$ & $118.930 \mathrm{~b}$ \\
\hline Yakutiye & $107.980 \mathrm{cf}$ & $104.642 \mathrm{gh}$ & $109.248 \mathrm{~cd}$ & $118.768 b$ \\
\hline Ç13 & $103.910 \mathrm{~h}$ & $106.278 \mathrm{dh}$ & $109.200 \mathrm{~cd}$ & $121.815 \mathrm{a}$ \\
\hline Zulbiye & $103.884 \mathrm{~h}$ & $105.388 \mathrm{eh}$ & $108.235 \mathrm{ce}$ & $122.059 \mathrm{a}$ \\
\hline \multicolumn{5}{|c|}{ Low temperatures } \\
\hline Ç30 & $102.226 \mathrm{e}^{*}$ & $116.015 \mathrm{~d}$ & $121.513 \mathrm{c}$ & $144.875 b$ \\
\hline Yakutiye & $101.283 \mathrm{e}$ & $116.510 \mathrm{~d}$ & $119.986 \mathrm{dc}$ & $146.259 b$ \\
\hline Ç13 & $102.829 \mathrm{e}$ & $124.475 \mathrm{c}$ & $122.594 \mathrm{c}$ & $157.812 \mathrm{a}$ \\
\hline Zulbiye & $102.738 \mathrm{e}$ & $124.662 c$ & $124.193 \mathrm{c}$ & $157.873 \mathrm{a}$ \\
\hline
\end{tabular}

*Means in control and low temperature followed by the same letter are not significantly different $(\mathrm{P}<0.05)$

Despite the insignificant differences in malondialdehyde (MDA) activity of the control groups in the $1^{\text {st }}$ and $2^{\text {nd }}$ periods, the MDA activity of Ç13 genotype was 
identified as $5.899 \mathrm{nmol} \mathrm{g}{ }^{-1} \mathrm{FW}$ in the $2^{\text {nd }}$ period. Significant increases were observed in MAD activities of the bean genotypes in the first two periods of low temperature stress (Table 9). The increase in MAD activity continued in the $3^{\text {rd }}$ period, Ç30 (5.954 $\mathrm{nmol} \mathrm{g}^{-}$ $\left.{ }^{1} \mathrm{FW}\right)$ and $\mathrm{Y}\left(5.981 \mathrm{nmol} \mathrm{g}^{-1} \mathrm{FW}\right)$ genotypes were placed in the same statistical group, Ç13 (6.248 $\left.\mathrm{nmol} \mathrm{g} \mathrm{g}^{-1} \mathrm{FW}\right)$ and $\mathrm{Z}\left(6.255 \mathrm{nmol} \mathrm{g}^{-1} \mathrm{FW}\right)$ were also placed in the same statistical group (Table 7). Such increases also continues in the $4^{\text {th }}$ period of low temperature stress, Ç30 bean genotype $\left(6.106 \mathrm{nmol} \mathrm{g}^{-1} \mathrm{FW}\right)$ and $\mathrm{Y}$ bean cultivar $\left(6.114 \mathrm{nmol} \mathrm{g}^{-1} \mathrm{FW}\right)$ were placed in the same statistical group, Ç13 genotype had an MDA activity of $6.325 \mathrm{nmol} \mathrm{g}^{-1} \mathrm{FW}$ and Zulbiye bean cultivar had an MDA activity of $6.373 \mathrm{nmol} \mathrm{g}^{-1} \mathrm{FW}$ (Table 9).

Table 11. Change in catalase (CAT mmol $\mathrm{g}^{-1}$ ) content of bean (Phaseolus vulgaris) genotypes under low temperature stress in 4 periods

\begin{tabular}{|c|c|c|c|c|}
\hline Genotype & $\begin{array}{c}\text { Period } 1 \\
\left(\text { day } 25^{\text {th }}\right)\end{array}$ & $\begin{array}{c}\text { Period } 2 \\
\left(\text { day } 30^{\text {th }}\right)\end{array}$ & $\begin{array}{c}\text { Period 3 } \\
\left(\text { day } 35^{\text {th }}\right)\end{array}$ & $\begin{array}{l}\text { Period } 4 \\
\left(\text { day } 40^{\text {th }}\right)\end{array}$ \\
\hline \multicolumn{5}{|l|}{ Control } \\
\hline Ç30 & $0.176 \mathrm{~d}^{*}$ & $0.186 \mathrm{c}$ & $0.193 b c$ & $0.196 \mathrm{~b}$ \\
\hline $\mathrm{Y}$ & $0.175 \mathrm{~d}$ & $0.184 \mathrm{c}$ & $0.193 b$ & $0.197 b$ \\
\hline Ç13 & $0.171 \mathrm{e}$ & $0.186 \mathrm{c}$ & $0.194 \mathrm{~b}$ & $0.210 \mathrm{a}$ \\
\hline $\mathrm{Z}$ & $0.167 \mathrm{f}$ & $\mathrm{c} 0.185 \mathrm{~h}$ & $0.196 \mathrm{~b}$ & $0.214 \mathrm{a}$ \\
\hline \multicolumn{5}{|c|}{ Low temperatures } \\
\hline Ç30 & $0.172 \mathrm{~h}^{*}$ & $0.184 \mathrm{f}$ & $0.203 \mathrm{df}$ & $0.217 \mathrm{c}$ \\
\hline $\mathrm{Y}$ & $0.176 \mathrm{gh}$ & $0.187 f$ & $0.203 \mathrm{df}$ & $0.224 b$ \\
\hline Ç13 & $0.178 \mathrm{~g}$ & $0.193 \mathrm{e}$ & $0.216 \mathrm{c}$ & $0.244 \mathrm{a}$ \\
\hline $\mathrm{Z}$ & $0.176 \mathrm{~g}$ & $0.186 f$ & $0.215 \mathrm{c}$ & $0.245 \mathrm{a}$ \\
\hline
\end{tabular}

*Means in control and low temperature followed by the same letter are not significantly different $(\mathrm{P}<0.05)$

Table 12. Change in ascorbate peroxidase (APX mmol $\mathrm{g}^{-1} \mathrm{FW}$ ) content of bean (Phaseolus vulgaris) genotypes under low temperature stress in 4 periods

\begin{tabular}{|c|c|c|c|c|}
\hline Genotype & $\begin{array}{c}\text { Period } 1 \\
\left(\text { day } 25^{\text {th }}\right) \\
\end{array}$ & $\begin{array}{c}\text { Period } 2 \\
\left(\text { day } 30^{\text {th }}\right) \\
\end{array}$ & $\begin{array}{c}\text { Period 3 } \\
\left(\text { day } 35^{\text {th }}\right)\end{array}$ & $\begin{array}{c}\text { Period } 4 \\
\left(\text { day } 40^{\text {th }}\right)\end{array}$ \\
\hline \multicolumn{5}{|l|}{ Control } \\
\hline Ç30 & $0.7331^{*}$ & $0.7591 \mathrm{j}$ & $0.781 \mathrm{f}$ & $0.812 \mathrm{~d}$ \\
\hline Yakutiye & $0.755 \mathrm{j}$ & $0.763 \mathrm{gh}$ & $0.793 \mathrm{e}$ & $0.826 \mathrm{c}$ \\
\hline Ç13 & $0.747 \mathrm{k}$ & $0.0 .766 \mathrm{~g}$ & $0.778 \mathrm{f}$ & $0.855 \mathrm{a}$ \\
\hline Zulbiye & $0.756 \mathrm{j}$ & $0.771 \mathrm{~g}$ & $0.791 \mathrm{e}$ & $0.836 \mathrm{~b}$ \\
\hline \multicolumn{5}{|c|}{ Low temperatures } \\
\hline Ç30 & $0.759 i^{*}$ & $0.766 \mathrm{~h}$ & $0.903 \mathrm{e}$ & $0.928 \mathrm{~d}$ \\
\hline Yakutiye & $0.731 \mathrm{k}$ & $0.771 \mathrm{~h}$ & $0.873 f$ & $0.923 \mathrm{~d}$ \\
\hline Ç13 & $0.747 \mathrm{j}$ & $0.784 \mathrm{~g}$ & $1.124 b$ & $1.162 \mathrm{a}$ \\
\hline Zulbiye & $0.742 j$ & $0.785 \mathrm{~g}$ & $1.116 \mathrm{c}$ & $1.167 \mathrm{a}$ \\
\hline
\end{tabular}

* Means in control and low temperature followed by the same letter are not significantly different $(\mathrm{P}<0.05)$ 
Table 13. Change in MDA (nmol $\left.g^{-1} F W\right)$, CAT (mmol $\left.g^{-1} F W\right)$, SOD (unit $\left.g^{-1} F W\right)$ and APX (mmol $g^{-1} F W$ ) content of control and low temperature stress treatments

\begin{tabular}{c|c|c|c|c|c|c|c|c}
\hline \multirow{2}{*}{ Genotype } & \multicolumn{2}{|c|}{ MDA } & \multicolumn{2}{c|}{ CAT } & \multicolumn{2}{c|}{ SOD } & \multicolumn{2}{c}{ APX } \\
\cline { 2 - 9 } & Control & $\begin{array}{c}\text { Low } \\
\text { temperatures }\end{array}$ & Control & $\begin{array}{c}\text { Low } \\
\text { temperatures }\end{array}$ & Control & $\begin{array}{c}\text { Low } \\
\text { temperatures }\end{array}$ & Control & $\begin{array}{c}\text { Low } \\
\text { temperatures }\end{array}$ \\
\hline Ç30 & $5.68 \mathrm{~b}^{*}$ & $5.89 \mathrm{~d}^{*}$ & $0.188 \mathrm{~b}$ & $0.194 \mathrm{~d}^{*}$ & $110.14 \mathrm{a}^{*}$ & $121.16 \mathrm{~b}^{*}$ & $0.771 \mathrm{c}^{*}$ & $0.839 \mathrm{~b}^{*}$ \\
Yakutiye & $5.69 \mathrm{ab}$ & $5.92 \mathrm{c}$ & $0.0 .187 \mathrm{~b}$ & $0.197 \mathrm{c}$ & $110.16 \mathrm{a}$ & $121.01 \mathrm{~b}$ & $0.784 \mathrm{~b}$ & $0.824 \mathrm{c}$ \\
Ç13 & $5.78 \mathrm{a}$ & $6.07 \mathrm{~b}$ & $0.190 \mathrm{a}$ & $0.208 \mathrm{a}$ & $110.31 \mathrm{a}$ & $127.17 \mathrm{a}$ & $0.786 \mathrm{ab}$ & $0.954 \mathrm{a}$ \\
Zulbiye & $5.71 \mathrm{ab}$ & $6.13 \mathrm{a}$ & $0.190 \mathrm{a}$ & $0.205 \mathrm{~b}$ & $109.89 \mathrm{a}$ & $127.36 \mathrm{a}$ & $0.788 \mathrm{a}$ & $0.952 \mathrm{a}$ \\
\hline
\end{tabular}

*Means in each column followed by the same letter are not significantly different $(\mathrm{P}<0.05)$

The changes in superoxide dismutase (SOD) activity of the bean genotypes under low temperature stress were not found to be significant in the $1^{\text {st }}$ period and they were all placed in the same statistical group. In the $2^{\text {nd }}$ period, Zulbiye $\left(124.662\right.$ unit $\left.\mathrm{g}^{-1} \mathrm{FW}\right)$ and Ç13 (124.475 unit $\mathrm{g}^{-1} \mathrm{FW}$ ) bean genotypes were placed in the same statistical group and Yakutiye (116.510 unit $\mathrm{g}^{-1} \mathrm{FW}$ ) and Ç30 (116.015 unit $\mathrm{g}^{-1} \mathrm{FW}$ ) bean genotypes were placed in the same statistical group. In the $4^{\text {th }}$ period of low temperature stress, greater increases were observed in the SOD activities of Ç13 (157.812 unit $\left.\mathrm{g}^{-1} \mathrm{FW}\right)$ and Zulbiye (157.873 unit $\mathrm{g}^{-1} \mathrm{FW}$ ) genotypes (Table 10). With regard to catalase (CAT) activity in the $1^{\text {st }}$ period of low temperature stress, Ç13 $\left(0.178 \mathrm{mmol} \mathrm{g}{ }^{-1} \mathrm{FW}\right)$ and Zulbiye $\left(0.176 \mathrm{mmol} \mathrm{g}^{-1} \mathrm{FW}\right)$ bean genotypes were placed in the same statistical group, but Yakutiye $\left(0.176 \mathrm{mmol} \mathrm{g}^{-1} \mathrm{FW}\right)$ and Ç30 $\left(0.172 \mathrm{mmol} \mathrm{g}^{-1} \mathrm{FW}\right)$ bean genotypes were significantly different from the other genotypes. A slight increase was observed in CAT activities of the genotypes in the $2^{\text {nd }}$ period of low temperature stress, but differences in CAT activities of the genotypes, except for Ç13, were not found to be significant. In the $3^{\text {rd }}$ period of stress, Ç30 and Yakutiye genotypes had a CAT activity of $0.203 \mathrm{mmol} \mathrm{g}^{-1}$ FW, Ç13 genotypes had a CAT activity of $0.216 \mathrm{mmol} \mathrm{g}^{-1} \mathrm{FW}$ and Zulbiye genotype had a value of $0.215 \mathrm{mmol} \mathrm{g}^{-1} \mathrm{FW}$. The differences among the genotypes were not significant, thus they were all placed in the sme statistical group. In the $4^{\text {th }}$ period of low temperature stress, the differences in CAT activities of the genotypes (Ç30: $0.217 \mathrm{mmol}$ $\mathrm{g}^{-1} \mathrm{FW}$; Y: $0.224 \mathrm{mmol} \mathrm{g}{ }^{-1} \mathrm{FW}$; Ç13: $0.244 \mathrm{mmol} \mathrm{g}{ }^{-1} \mathrm{FW}$; Z: $\left.0.245 \mathrm{mmol} \mathrm{g}{ }^{-1} \mathrm{FW}\right)$ were found to be significant (Table 11). With regard to ascorbate peroxidase (APX) activity of the $1^{\text {st }}$ period, Ç13 $\left(0.747 \mathrm{mmol} \mathrm{g}^{-1} \mathrm{FW}\right)$ and Zulbiye $\left(0.742 \mathrm{mmol} \mathrm{g}{ }^{-1} \mathrm{FW}\right)$ bean genotypes were placed in the same statistical group, thus the difference between them were not significant. Yakutiye $\left(0.731 \mathrm{mmol} \mathrm{g}^{-1} \mathrm{FW}\right)$ and Ç30 $\left(0.759 \mathrm{mmol} \mathrm{g}{ }^{-1} \mathrm{FW}\right)$ bean genotypes were found to be significantly different from the other genotypes. In the $2^{\text {nd }}$ period of stress, there was a slight increase in APX activity of the sensitive and tolerant genotypes and the differences in APX activity of sensitive and tolerant genotypes were found to be significant. There were significant differences in APX activity of the genotypes in the $3^{\text {rd }}\left(C ̧ 30: 0.903 \mathrm{mmol} \mathrm{g}^{-1} \mathrm{FW}\right.$; Y: $0.873 \mathrm{mmol} \mathrm{g}^{-1} \mathrm{FW}$; Ç13: $\left.1.124 \mathrm{mmol} \mathrm{g}^{-1} \mathrm{FW} ; \mathrm{Z}: 1.116 \mathrm{mmol} \mathrm{g}^{-1} \mathrm{FW}\right)$ and $4^{\text {th }}\left(C ̧ 30: 0.928 \mathrm{mmol} \mathrm{g}{ }^{-1} \mathrm{FW} ; \mathrm{Y}\right.$ : $0.923 \mathrm{mmol} \mathrm{g}^{-1} \mathrm{FW}$; Ç13: $1.162 \mathrm{mmol} \mathrm{g}^{-1} \mathrm{FW}$; Z: $1.167 \mathrm{mmol} \mathrm{g}^{-1} \mathrm{FW}$ ) period of low temperature stress (Table 12).

Period-dependent differences in MDA, CAT, SOD and APX activity of control and low temperature treatments were found to be significant. Low temperature-tolerant Yakutiye cultivar had the values of MDA: $5.69 \mathrm{nmol} \mathrm{g}^{-1} \mathrm{FW}, \mathrm{CAT}: 0.187 \mathrm{mmol} / \mathrm{g} \mathrm{FW}$, 
SOD: 110.16 unit $\mathrm{g}^{-1} \mathrm{FW}$, APX: $0.784 \mathrm{mmol} \mathrm{g}^{-1} \mathrm{FW}$ in control treatments and had the values of MDA: $5.92 \mathrm{nmol} \mathrm{g}^{-1} \mathrm{FW}$, CAT: $0.197 \mathrm{mmol} \mathrm{g}{ }^{-1} \mathrm{FW}$, SOD: $121.01 \mathrm{unit}^{-1}$ FW, APX: $0.824 \mathrm{mmol} \mathrm{g}^{-1} \mathrm{FW}$ in low temperature treatments. Low temperaturesensitive Zulbiye cultivar had the values of MDA: $5.71 \mathrm{nmol} \mathrm{g}^{-1} \mathrm{FW}$, CAT: $0.190 \mathrm{mmol}$ $\mathrm{g}^{-1} \mathrm{FW}$, SOD: 109.89 unit g$^{-1} \mathrm{FW}$, APX: $0.788 \mathrm{mmol} \mathrm{g}^{-1} \mathrm{FW}$ in control treatments and had the values of MDA: $6.13 \mathrm{nmol} \mathrm{g}^{-1} \mathrm{FW}$, CAT: $0.205 \mathrm{mmol} \mathrm{g}^{-1} \mathrm{FW}$, SOD: 127.36 unit $\mathrm{g}^{-1} \mathrm{FW}$, APX: $0.952 \mathrm{mmol} \mathrm{g}^{-1} \mathrm{FW}$ in low temperature treatments.

Significant findings were obtained for investigated parameters of present study both in control and low temperature stress treatments. Among the investigated parameters, decreases were observed in chlorophyll and ion contents of the genotypes in 4 periods and increases were observed in MDA, CAT, SOD and APX activity of the genotypes. The differences between the genotypes and between the periods were found to be significant.

\section{Discussion}

Some significant recession is observed in plant growth and development under low temperatures. This recession is greater in low temperature-sensitive genotypes. In the present study, changes in chlorophyll, $\mathrm{K}, \mathrm{Ca}$, and $\mathrm{Mg}$ contents and lipid peroxidation (MDA), catalase (CAT), superoxide dismutase (SOD) and ascorbate peroxidase (APX) activities of low temperature-tolerant and sensitive bean (Phaseolus vulgaris) genotypes were investigated in four different periods of low temperature stress. Present findings were quite similar with the findings of the earlier studies.

There were decreases in chlorophyll a, chlorophyll b and total chlorophyll contents of tolerant and sensitive genotypes in four periods (Tables 1-3). Such decreases were greater in low temperature sensitive Ç13 and Zulbiye (Z) genotypes than in low temperature-tolerant Ç30 and Yakutiye (Y) bean genotypes. There were also significant differences in investigated parameters of the control and low temperature treatments of four periods (Table 4). Decreases were reported in chlorophyll a, chlorophyll b and total chlorophyll contents of bean and tomato plants under abiotic stress conditions (Terzi et al., 2010; Kabay and Şensoy, 2016, 2017; Alp and Kabay, 2017). Similar findings were reported in literature about the effects of different low temperatures. It was reported in a previous study investigating the effects of low temperature stress on physiological characteristics of tomato genotypes that cold stress reduced chlorophyll and dry matter content of young and old leaves (Gökmen, 2006). Low temperatures increased chlorophyll and weight losses of cabbages (Soengas et al., 2018). Cold stress decreased photosynthetic processes of tea leaves, but melatonin treatments reduced antioxidant potential and oxidative stress and increased photosynthetic capacity (Li et al., 2018). Low temperatures $\left(14 / 12{ }^{\circ} \mathrm{C}\right)$ altered osmatic potential of maize leaf cells and ultimately altered cell membrane composition (Bilska-kos et al., 2017).

In control groups, significant increases were observed in potassium $(\mathrm{K})$, calcium $(\mathrm{Ca})$ and Magnesium ( $\mathrm{Mg}$ ) content of bean (Phaseolus vulgaris) genotypes in four periods. The changes in $\mathrm{K}, \mathrm{Ca}$ and $\mathrm{MG}$ content of bean genotypes under low temperature stress were also found to be significant and $\mathrm{K}, \mathrm{Ca}$ and $\mathrm{Mg}$ contents decreased in four periods. Such decreases were greater in stress-sensitive genotypes (Tables 5-7). The decreases in $\mathrm{K}$ content of Yakutiye (Y) bean cultivar in the $2^{\text {nd }}$ and 3 rd periods were not found to be significant. The decreases in $\mathrm{K}$ content of $\mathrm{cv}$. Zulbiye in the $3^{\text {rd }}$ and $4^{\text {th }}$ periods were also not found to be significant (Table 5). The changes in $\mathrm{Ca}$ and $\mathrm{Mg}$ contents were 
found to be significant in the $4^{\text {th }}$ period of stress (Tables 6 and 7). Throughout 4 periods, changes in $\mathrm{K}, \mathrm{Ca}$ and $\mathrm{Mg}$ content of bean genotypes in control and low temperature treatments were found to be significant and ion contents decreased under low temperature stress (Table 8).

It was reported that low temperature stress negatively influenced leaf cells of maize plants (Bilska-kos et al., 2017). Low soil temperatures in spring negatively influence seedling growth and development of sensitive bean plants (Elkoca et al., 2005). Low temperature stress was reported to have negative effects on cold stress-resistant and sensitive sugar cane cultivars (Sun et al., 2017). It was reported in study carried out to determine total temperature demands of bean plants at different growth stages that the greatest yield was obtained from early July sowings and yields decreased as the sowing time approached to autumn (Yoldaş and Eşiyok, 2009). High and low temperatures $\left(15 / 8,20 / 13,28 / 21,33 / 23\right.$ and $\left.36 / 26{ }^{\circ} \mathrm{C}\right)$ were applied to tomato plants and it was observed that temperature stress negatively influenced plant growth and development and nutrient uptake (Sung et al., 2015). In vegetables, low temperatures at root zone generate a stress in water absorption of the roots (Sakamoto and Suzuki, 2015). Decreasing chlorophyll, $\mathrm{K}$ and $\mathrm{Ca}$ contents were reported for bean and tomato plants under abiotic stress (Terzi et al., 2010; Kabay and Şensoy, 2016; Zhou et al., 2017; Uzal and Yasar, 2017; Kabay et al., 2017; Alp and Kabay, 2017)

Significant differences were observed in MDA contents of the bean plants in 4 periods and increases were observed at the end of $4^{\text {th }}$ period as compared to the $1^{\text {st }}$ period. Such increases were greater in low temperature sensitive bean genotypes (Table 7). Similar changes were also observed in CAT, SOD and APX antioxidative enzyme activities. Increases were observed in CAT, SOD and APX activities of the bean genotypes in 4 periods. Increases were greater in the $4^{\text {th }}$ period as compared to the $1^{\text {st }}$ period and increases were also greater in low temperature-sensitive bean genotypes (Table 9-12). With regard to MDA activity, there were significant differences both between the bean genotypes and between the stress periods (Table 9). There were significant differences in superoxide dismutase (SOD) activity of the bean genotypes in the $4^{\text {th }}$ period of stress. However, the differences in SOD activity of Ç13 and Zulbiye genotypes were not significant different in the $2^{\text {nd }}$ and $3^{\text {rd }}$ period of the stress (Table 10). There were significant differences in catalase (CAT) activity of both the bean genotypes and the stress periods (Table 11). The changes in CAT activity of Ç30 and Yakutiye bean genotypes were not found to be significant in $2^{\text {nd }}$ and $3^{\text {rd }}$ period of stress (Table 11). The differences in ascorbate peroxidase (APX) activity of both the genotypes and the stress periods were also found to be significant (Table 12). Both the control and the low temperature treatments yielded significant differences in MDA, CAT, SOD and APX activity of the bean genotypes. Significant increases were observed in MDA, CAT, SOD and APX activities under low temperature stress (Table 13). Xintaimici and Jinyan cucumber (Cucumis sativus L.) cultivars were subjected to two different temperature regimes $\left(15 / 15^{\circ} \mathrm{C}\right.$ and $\left.25 / 18{ }^{\circ} \mathrm{C}\right)$ under low light intensity and significant increases were reported in leaf superoxide dismutase and less increases were reported in leaf catalase activity (Xu et al., 2008). Increasing ascorbate peroxidase (APX) and superoxide dismutase (SOD) activities of melon and pumpkin plants were reported under low temperature conditions (Do et al., 2018).

In process of cold resistance, plants develop different mechanisms against cold stress-induced damages and ultimate die outs or develop such mechanisms to provide cold-tolerance such as physical changes in cell membranes, changes in some soluble 
substances in plant extract, lipid composition of cell membranes, protein contents, enzyme activity and antioxidant systems and plant nutrients (Aslantaş et al., 2010). It was reported in a previous study investigating the effects of low temperature stress on physiological characteristics of tomato genotypes that young and old leaves of the plants were found to be insufficient in antioxidative systems (Gökmen, 2006). Low temperatures were reported to increase antioxidant enzyme and MDA content of rapeseed plants (Xian et al., 2017). Low temperatures increased chlorophyll and weight losses of cabbages and increased reactive oxygen species (Soengas et al., 2018). In a previous study carried out with cold stress resistant and sensitive sugar cane cultivar, cell structure was destructed and cold stress-induced plants had greater MDA, proline, soluble sugar, soluble protein, POD and SOD activity than the control plants (Sun et al., 2017). It was reported in another study investigating the effects of cold stress on rye and wheat seedlings that cold stress increased antioxidant enzyme activities, proline, sugar and anthocyanins contents of both species (Kolupaev et al., 2016). Significant decreases were reported in malondialdehyde, proline, peroxidase and catalase activities of control and transgenic tomato plants under cold and low temperature stress (Yu et al., 2015). While significant increases were reported in antioxidant compound quantities of tomato plants, decreases were reported in chlorophyll contents (Gökmen, 2006). In present study, significant decreases were observed in chlorophyll, $\mathrm{K}, \mathrm{Ca}$ and $\mathrm{Mg}$ contents and increases were observed in MDA, CAT, SOD and APX activities of bean genotypes under low temperature conditions. Present findings were mostly well complied with the results of similar earlier studies.

\section{Conclusion}

Significant differences were observed in chlorophyll contents, enzyme activities and ion contents of low temperature-resistant and sensitive common bean (Phaseolus vulgaris) genotypes throughout cold stress treatments. The decrease in chlorophyll-a, chlorophyll-b, total chlorophyll, $\mathrm{K}, \mathrm{Ca}$ and $\mathrm{Mg}$ contents were greater in low temperature-sensitive bean plants than in low temperature-tolerant plants.

With the progress of cold stress, the MDA content of sensitive genotypes were greater than the MAD contents of tolerant genotypes. On the other hand, tolerant genotypes had greater CAT, SOD and APX antioxidant enzyme activities than the sensitive genotypes. Present findings proved one more time the suitability of the parameters selected to determine the effects of low temperature stress for selection of drought stress-tolerant bean genotypes.

\section{REFERENCES}

[1] Alp, Y., Kabay, T. (2017): The effect of drought stress on plant development in some native and commercial tomato genotypes. - Yuzuncu Yil University Journal of Agricultural Sciences 27(3): 387-395.

[2] Amira, M. S., Qados, A. (2011): Effect of salt stress on plant growth and metabolism of bean plant Vicia faba (L.). - Journal of the Saudi Society of Agricultural Sciences 10: 715.

[3] Aslantaş, R., Karakurt, H., Karakurt, Y. (2010): The cellular and molecular mechanisms on resistance to low temperatures in plants. - Ataturk University Journal of the Faculty of Agriculture 41(2). 
[4] Bagc1, E. G. (2010): Identification of drought-induced oxidative stress in chickpea with physiological and biochemical parameters. - Unpublished Ph. D. Thesis, Ankara University Faculty of Science.

[5] Bilska-Kos, A., Solecka, D., Dziewulska, A., Ochodzki, P., Jończyk, M., Bilski, H., Sowiński, P. (2017): Low temperature caused modifications in the arrangement of cell wall pectins due to changes of osmotic potential of cells of maize leaves (Zea mays L.).Protoplasma 254(2): 713-724.

[6] Do, T. H., Nguyen, H. C., Lin, K. H. (2018): The responses of antioxidant system in bitter melon, sponge gourd, and winter squash under flooding and chilling stresses. - AIP Conference Proceedings 1954(1): 020001.

[7] Elkoca, E., Kantar, F., Eleman, G., Şat, İ. G. (2005): Determination of cold resistant dry bean (Phaseolus vulgaris 1.) genotypes under field conditions. - Atatürk University Journal of the Faculty of Agriculture 36(1).

[8] Georgieva, K., Szigeti, Z., Sarvari, E., Gaspar, L., Maslenkova, L., Peeva, V., Tuba, Z. (2007): Photosynthetic activity of homoiochlorophyllous desiccation tolerant plant Haberlea rhodopensis during dehydration and rehydration. - Planta. 225(4): 955-964.

[9] Gökmen, Ö. Ö. (2006): Investigation of antioxidative mechanisms of domateste cold stress. - Unpublished Ph. D. Thesis, Cukurova Institute of Natural and Applied Sciences.

[10] Huang, C., Qin, N., Sun, L., Yu, M., Hu, W., Qi, Z. (2018): Selenium improves physiological parameters and alleviates oxidative stress in strawberry seedlings under low-temperature stress. - International Journal of Molecular Sciences 19(7): 1913.

[11] Heath, R. L., Packer, L. (1968): Photoperoxidation in isolated chloroplasts: II. role of electron transfer. - Archives of Biochemistry and Biophysics 125(3): 850-857.

[12] Jebara, S., Jebara, M., Liman, F., Aouani, E. (2005): Changes in ascorbate peroxidase, catalase, guaicol peroxidase and superoxide dismutase activities in common bean nodules under salt stres. - J. of Plant Physiol. 162: 929-936.

[13] Kabay, T., Şensoy, S. (2016): Drought stress-induced changes in enzymes, chlorophyll and ions of some bean genotypes. - Yuzuncu Y1l University Journal of Agricultural Sciences 26(3): 380-395.

[14] Kabay, T., Șensoy, S. (2017): Enzyme, chlorophyll and ion changes in some common bean genotypes by high temperature stress. - Ege University Journal of Agricultural Sciences 54(4): 429-437.

[15] Kabay, T., Erdinç, Ç., Şensoy, S. (2017): Effects of drought stress on plant growth parameters membrane damage index and nutrient content in common bean genotypes. The Journal of Animal and Plant Sciences. 27(3). Page: 940-952.

[16] Kacar, B. (1994): Plant and Soil Chemical Analysis; III: Soil Analysis. - Issue No. 3, A. Ü. Agriculture Foundation, Ankara.

[17] Kacar, B., Inal, A. (2008): Plant Analysis. - Nobel Press, Ankara.

[18] Kolupaev, Y. E., Yastreb, T. O., Oboznyi, A. I., Ryabchun, N. I., Kirichenko, V. V. (2016): Constitutive and cold-induced resistance of rye and wheat seedlings to oxidative stress. - Russian Journal of Plant Physiology 63(3): 326-337.

[19] Kuşvuran, Ş. (2010): Relationships between physiological mechanisms for drought and salinity tolerance of melons. - Unpublished $\mathrm{Ph}$. D. Thesis, Çukurova University Institute of Natural and Applied Sciences.

[20] Li, X., Wei, J. P., Scott, E. R., Liu, J. W., Guo, S., Li, Y., Han, W. Y. (2018): Exogenous melatonin alleviates cold stress by promoting antioxidant defense and redox homeostasis in camellia sinensis L. - Molecules 23(1): 165.

[21] Lichtenthaler, H. K., Wellburn, A. R. (1983): Determinations of total careteonids and chlorophylls $\mathrm{a}$ and $\mathrm{b}$ of leaf extracts in different solvents. - Biomchem. Soc. Transac. 11: 591-592.

[22] Ogweno, J. O., Song, X. S., Hu, W. H., Shi, K., Zhou, Y. H., Yu, J. Q. (2009): Detached leaves of tomato differ in their photosynthetic physiological response to moderate high and low temperature stress. - Scientia Horticulturae 123(1): 17-22. 
[23] Rahnama, H., Ebrahimzadeh, H. (2005): The effect of $\mathrm{NaCl}$ on antioxidant enzyme activities in potato seedlings. - Biol. Planta. 49: 93-97.

[24] Sairam, R. K., Saxena, D. C. (2000): Oxidative stres and antioksidants in wheat genotypes: possible mechanism of water stres tolerance. - J. Agron. and Crop Sci. 184: 55-61.

[25] Sairam, R. K., Srivastava, G. C., Agarwal, S., Meena, R. C. (2005): Differences in antioxidant activity in response to salinity stress in tolerant and susceptible wheat genotypes. - Biol. Planta. 49: 85-91.

[26] SAS (2018): SAS/Stat Software Hangen and Enhanced. - SAS Institute Incorporation, Cary, NC.

[27] Sakamoto, M., Suzuki, T. (2015): Effect of root-zone temperature on growth and quality of hydroponically grown red leaf lettuce (Lactuca sativa L. cv. Red Wave). - American Journal of Plant Sciences 6(14): 2350.

[28] Soengas, P., Rodríguez, V. M., Velasco, P., Cartea, M. E. (2018): Effect of temperature stress on antioxidant defenses in brassica oleracea. - ACS Omega 3(5): 5237-5243.

[29] Sun, B., Liu, G. L., Phan, T. T., Yang, L. T., Li, Y. R., Xing, Y. X. (2017): Effects of cold stress on root growth and physiological metabolisms in seedlings of different sugarcane varieties. - Sugar Tech 19(2): 165-175.

[30] Sung, J., Lee, S., Lee, Y., Ha, S., Song, B., Kim, T., Krishnan, H. B. (2015): Metabolomic profiling from leaves and roots of tomato (Solanum lycopersicum L.) plants grown under nitrogen, phosphorus or potassium-deficient condition. - Plant Science 241: $55-64$.

[31] Uzal, O., Yasar, F. (2017): Effects of Ga3 hormone treatments on ion uptake and growth of pepper plants under cadmium stress. - Applied Ecology and Environmental Research 15(4): 1347-1357.

[32] Terzi, R., Sağlam, A., Kutlu, N., Nar, H., Kadioğlu, A. (2010): Impact of soil drought stress on photochemical efficiency of photosystem II and antioxidant enzyme activities of Phaseolus vulgaris cultivars. - Turkish Journal of Botany 34(1) 1-10.

[33] Xian, M., Luo, T., Khan, M. N., Hu, L., Xu, Z. (2017): Identifying differentially expressed genes associated with tolerance against low temperature stress in Brassica napus through transcriptome analysis. - International Journal of Agriculture Biology 19(2).

[34] Xu, P. L., Guo, Y. K., Bai, J. G., Shang, L., Wang, X. J. (2008): Effects of long-term chilling on ultrastructure and antioxidant activity in leaves of two cucumber cultivars under low light. - Physiologia Plantarum 132(4): 467-478.

[35] Yesilova, A., Denizhan, E. (2016): Modelling mite counts using Poisson and negative binomial. - Fresenius Environmental Bulletin. 25: 5062-5066.

[36] Yoldas, F., Esiyok, D. (2009): The influence of temperature on growth and yield of green beans for processing. - International Journal of Agricultural Research 4(3): 124-130.

[37] Yu, X. H., Juan, J. X., Gao, Z. L., Zhang, Y., Li, W. Y., Jiang, X. M. (2015): Cloning and transformation of inducer of CBF expression1 (ICE1) in tomato. - Genet Mol Res. 14: 13131-13143.

[38] Zhou, R., Kjær, K. H., Rosenqvist, E., Yu, X., Wu, Z., Ottosen, C. O. (2017): Physiological response to heat stress during seedling and anthesis stage in tomato genotypes differing in heat tolerance. - Journal of Agronomy and Crop Science 203(1): $68-80$. 